\title{
The Educational Needs of the Social Sciences High School teachers
}

\author{
Gholam Reza AHMADI, Batoul BASSIRI
}

University of Isfahan, Iran

\begin{abstract}
This study is intended to survey the educational needs of the social sciences high school and guidance school teachers in Isfahan. Hence, the educational needs of high school teachers for teaching skills, counselling, Audio-visual - aids, psychology, evaluation, planning and human relations were classified and studied. The population under study comprised of all social sciences teachers, male and female, teaching at high school and guidance schools in Isfahan. 155 teachers were elected by cluster sampling.
\end{abstract}

The research methodology was one of descriptive survey and the instrument comprising of 32 close questions on Likert scale. Next, the collected data was analysed using the descriptive and inferential methodology. The result of the study indicated that ranking high school teachers with reference to educational needs were not equal and that ranking the educational needs of teachers consisted as the following priority:

1.technology and educational aids. 2. Educational psychology. 3.counselling and advisory services. 4.teaching skills. 5.evaluation skills. 6.instructional planning. 7.human relations.

Key words: educational needs, high school teachers, teaching skills, counselling

\section{Introduction}

Today there is a crucial need for lifelong learning. More and more people, many well beyond traditional college age, are seeking opportunities for continuing education to expand their intellectual horizons, to develop a better understanding of society and its institution, and to gain new knowledge to enable them to cope with rapid change. Other, confronted by the growing complexity of technology, seek retraining to upgrade their 
skills or prepare for entirely new careers. (Boyle 1981.p.3)

In fact, the recent changes in the socio-economic developments create specific needs for the skilled manpower. One such need are the educational programs for the majority of employees intended to upgrade the skills needed by them (Holinsheed. P. $15)$.

In fact, the recent changes in the socio-economic developments create specific needs for the skilled manpower. One such need are the educational programs for the majority of employees intended to upgrade the skills needed by them (Holinsheed.1993. P. 15).

A carefully worked out plan for needs assessment can protect against the least organizational dissociation. The success of a need's analysis plan depends to a great extent on the size of supports provided by the organization (Goldstein, 1993. P. 32).

Austin (1989) has conducted a study titled:" Needs assessment of Computer Specialists for the Oakland Faculty of Communications “. The study recommends four educational programs for the faculty:

1.Computerized Program for Commerce. 2. Computerized Analytical Methods. 3. Computerized Scientific Technology. 4. Technology of Micro-computerized Systems.

Quoting Sinha, Monappa (1989) has proposed methods for locating educational needs which include:

1. Opinion survey of CED'S. 2. Performance evaluation. 3. Programs for the sections and divisions of organizations. 4. Opinion survey of training directors. 5. Job analysis. 
Bowen (1994) is of the opinion that there are multiple possible classifications for educational needs. However, the opinions are divided for priority ordering. Further, in a study conducted by Miller (1992), reference has been made to four classes:

\section{Human Relations. 2. Communicative skills. 3. Employees'skills.}

4.Instrumental skills, and that the most important need focused on in this classification are human communications. He also classifies as educational needs the social communications, social motives, communicative services and extra-organizational expectations affecting the members' decisions to participate in educational programs.

Abedi (1991) in a study titled:” A survey of ways for Adapting the Literacy Education to the Needs and conditions of Literacy Program learners at the University of Isfahan "concluded that the educational content particularly in terms of adaptation to the Job-related needs of literacy learners does call for substantial modifications and revisions. More, irrelevance of educational material to the life needs of literacy novices are among the most important reasons for the failure of literacy programs across the nation.

In a study titled" A survey and recognition of the educational needs and impediments to teaching in the opinion of instructors of training courses in the rural areas of Isfahan ," Karbassyoun (1994) concludes that most of the instructors at issue had a positive attitude toward the general and specific educational needs and that for the general educational needs they placed on the priority list, the education of adults, the education of the youths, knowledge of the methods and techniques of teaching, application of psychology in teaching and the educational technology.

Nassiri (1994) in a study titled:” A survey of the elementary school teachers in Hormozgan "holds that the educational needs of the teachers must be recognized prior to the implementation of educational planning.

Ali Beigi (1996) in a study titled:” A survey of the educational needs of the agricultural engineers in Isfahan province "concludes the following: 
The five needs of the people under study include general information on development, educational technology, renovation, adult education and development methods respectively.

More, there was a significant relation between the work experience and the educational needs of agriculture engineers.

\section{Methodology and Materials}

The method employed for this study is a descriptive survey studying the educational needs of the social sciences middle school and high school teachers for the five districts in Isfahan.

The statistical population for this study comprises the male and female social sciences teachers of Isfahan in the academic year 1999-2000.

Of the total 769 high school teachers 155 were randomly selected in cluster sampling using a pilot study, estimated population variance and the formula for sample size. The measurement tool for this study consisted of the researcher developed 32-close question inventory based on the Likert five-division scale. Based on Cronbach's Alpha, the reliability coefficient for the inventory was an estimated 95\% significant at an Alpha level of $1 \%$ indicating a highly valid measurement tool. The face validity of the inventory was examined on the expert advice of specialists and professionals.

The data from this study were analysed both descriptively and inferentially. Descriptively, the data were analysed using such statistical indicators as frequency, percentile, means and standard deviation. Inferentially, as the distribution of the scores for each area of educational needs was not normal and that the data were of a noninterval nature, Mannwhitney and Kruscall's non-parametric tests were used. 


\section{Analysis of the Data from the Inventory Items}

Table I -Frequency distribution and the percentage of the high school teachers' responses to the inventory questions concerning the First question of the study: To what extent are the high school teacher' educational needs in Job-related skills?

\begin{tabular}{|c|c|c|c|c|c|}
\hline $\begin{array}{l}\text { Itm To what extent do you need } \\
\text { Very Mean }\end{array}$ & Freq. & Very & $\mathrm{A}$ & Some & $\mathrm{A}$ \\
\hline $\begin{array}{l}\text { No. training in: } \\
\text { little weight }\end{array}$ & percent & much & lot & what & little \\
\hline $\begin{array}{l}\text { 5. Write all lesson plans ( daily, } \\
22 \quad 2.97\end{array}$ & Freq. & 14 & 39 & 52 & 28 \\
\hline $\begin{aligned} & \text { Weekly,...) } \\
14.2 & \end{aligned}$ & percent & 9 & 25.2 & 33.5 & 18.2 \\
\hline $\begin{array}{l}\text { 9. Write behavioural objectives } \\
15 \quad 3.19\end{array}$ & Freq. & 15 & 48 & 58 & 19 \\
\hline $\begin{array}{l}\text { In all areas } \\
9.7\end{array}$ & percent & 9.7 & 31 & 37.4 & 12.3 \\
\hline $\begin{array}{l}\text { 21. Ability to analyse textbooks } \\
9 \quad 3.74\end{array}$ & Freq. & 43 & 54 & 41 & 8 \\
\hline 5.8 & Percent & 27.7 & 34.8 & 26.5 & 5.2 \\
\hline $\begin{array}{l}\text { 23. Understand the various } \\
3 \quad 3.87\end{array}$ & Freq. & 47 & 59 & 34 & 12 \\
\hline $\begin{array}{ll} & \text { Strategies for teaching } \\
1.9 & \end{array}$ & percent & 30.3 & 38.1 & 21.9 & 7.7 \\
\hline
\end{tabular}




\begin{tabular}{|c|c|c|c|c|c|}
\hline $\begin{array}{l}\text { 27. The discipline and subject } \\
11 \quad 3.70\end{array}$ & Freq. & 44 & 51 & 41 & 8 \\
\hline $\begin{array}{ll} & \text { To be taught } \\
7.1 & \end{array}$ & percent & 28.4 & 38.9 & 26.5 & 5.2 \\
\hline $\begin{array}{l}\text { 29. Apply the techniques for } \\
9 \quad 3.46\end{array}$ & Freq. & 28 & 59 & 34 & 25 \\
\hline $\begin{array}{lll} & \text { Asking questions } \\
5.8 & & \end{array}$ & percent & 18.01 & 38.1 & 21.9 & 16.1 \\
\hline
\end{tabular}

As seen from the findings in table 1, the greatest percentage of responses were "And" for question "with $68.4 \%$ and for Question 21 with 62.5\%.

Table II - To what extent are the high school teachers' needs for Counselling and advisory services?

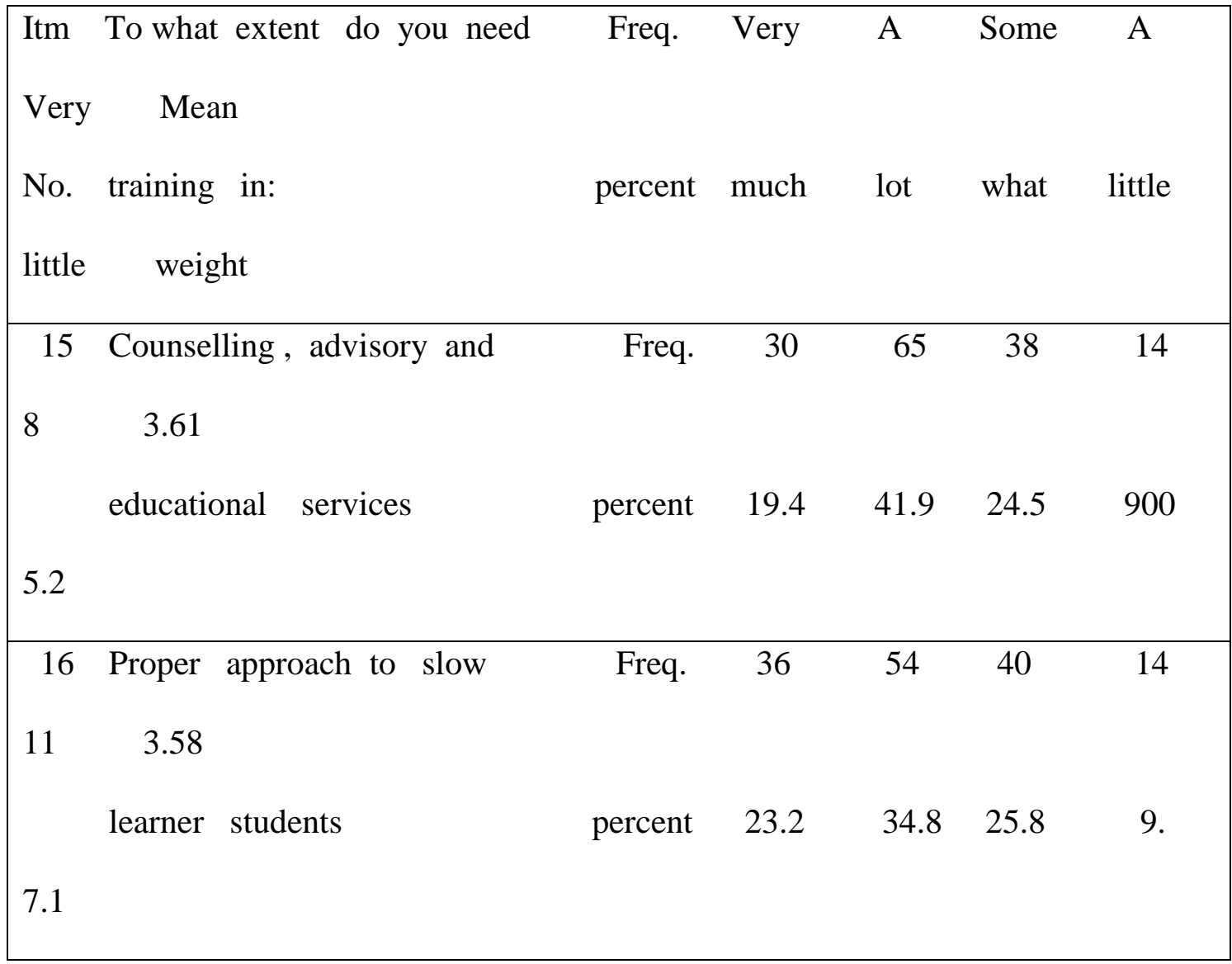




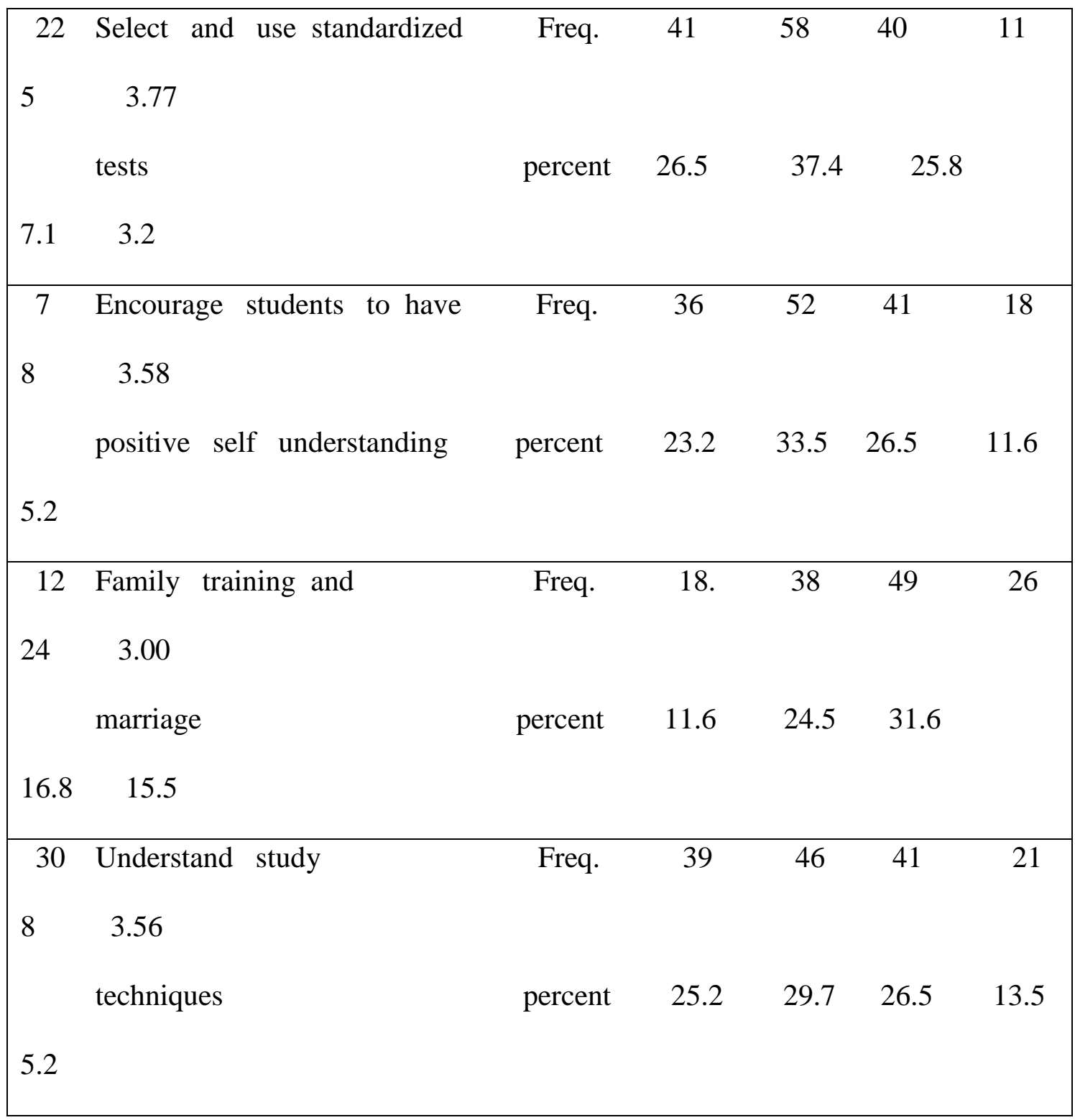

The greatest percentage of responses question 22 with $63.9 \%$ and for question 15 with $61.3 \%$ and the smallest educational need stated for question 12 with $36.1 \%$.

Table III - To what extent do high school teachers need technology and Audiovisual aids?

\begin{tabular}{|lrlllll|}
\hline Itm & To what extent do you need & Freq. Very A & Some & A \\
Very $\quad$ Mean & & & & & \\
No. training in: & percent & much lot & what little \\
little & weight & & & & & \\
\hline
\end{tabular}




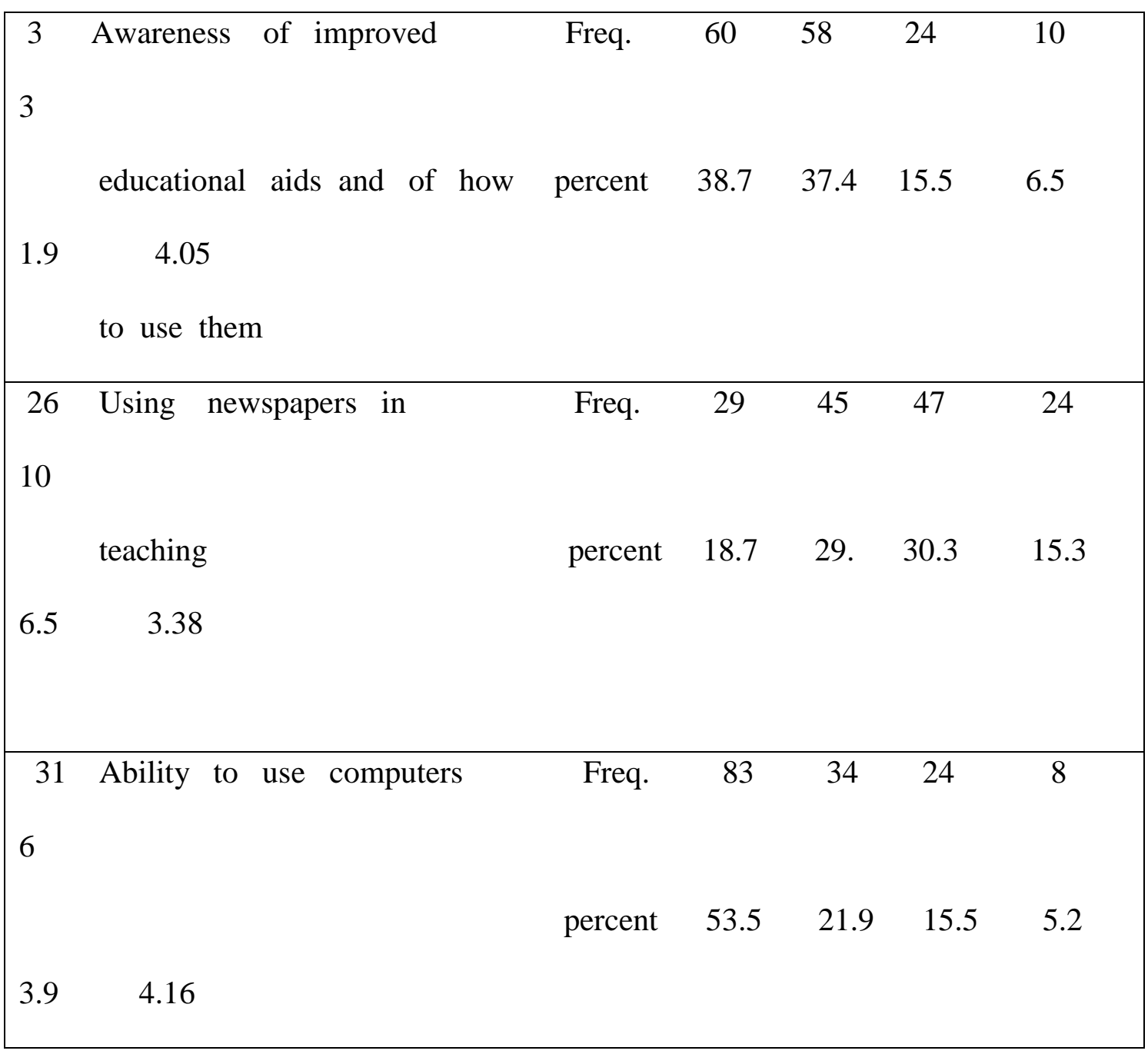

The greatest percentage of questions were for question 3 with $76.1 \%$ and question 31 with $75.4 \%$ and the smallest need of high school teachers' was for question 26 with $47.7 \%$.

Table IV - To what extent do high school Teachers need educational psychology?

\begin{tabular}{lllllll}
\hline Itm To what extent do you need & Freq. & Very A & Some & A \\
Very & Mean & & & & & \\
No. training in : & percent much lot & what little \\
little & weight & & & & &
\end{tabular}




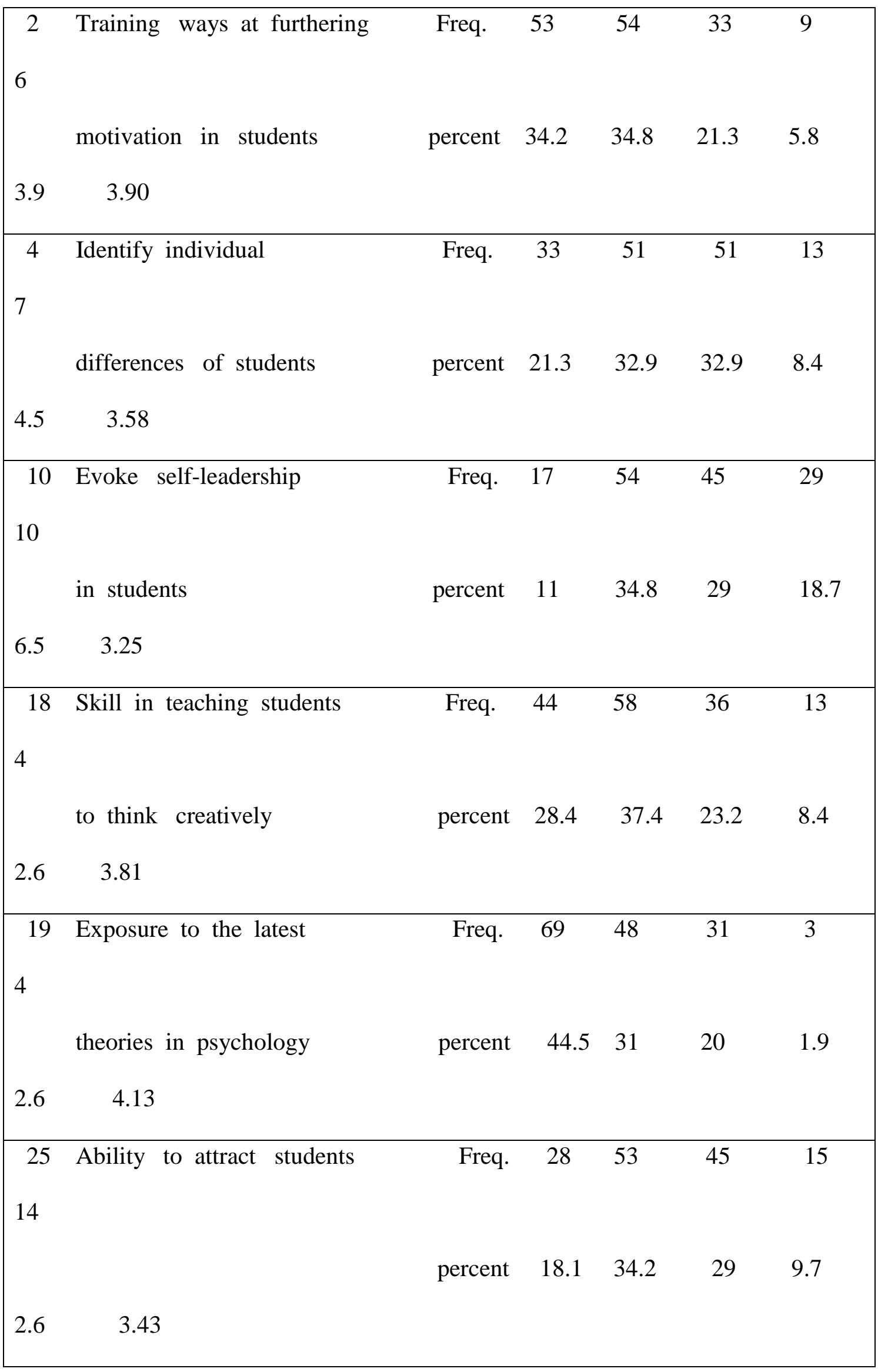




\begin{tabular}{|lllllll|}
\hline 28 & How to use disciplinary & Freq. & 26 & 42 & 53 & 23 \\
11 & & & & & & \\
& method? & Percent & 16.8 & 27.1 & 34.2 & 14.8 \\
7.1 & 3.32 & & & & & \\
\hline
\end{tabular}

The greatest percentage of responses pertains to question with $75.5 \%$ and question 3 with $69 \%$ and the smallest need of the high school teachers pertains to question with $43.9 \%$.

Table V- To what extent do high school teachers need to evaluational devices?

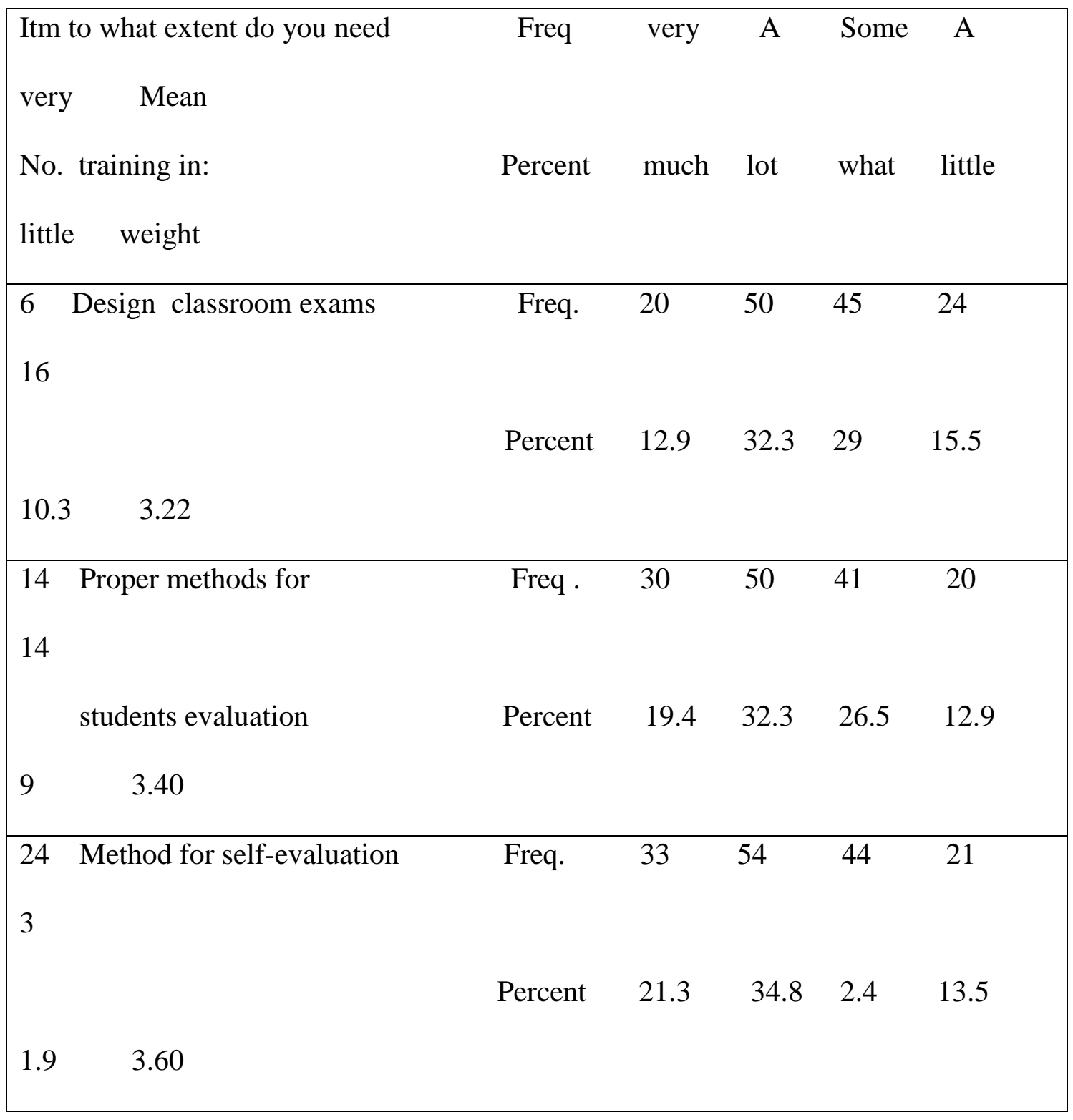


In view of the data provided in table $\mathrm{V}$, the greatest percentage of responses pertains to question 24 with $56.1 \%$ and to question 14 with $51.7 \%$ and the smallest need of high school teachers for training pertains to question 6 with $45.2 \%$.

Table VI- To what extent do high school teachers need human relations?

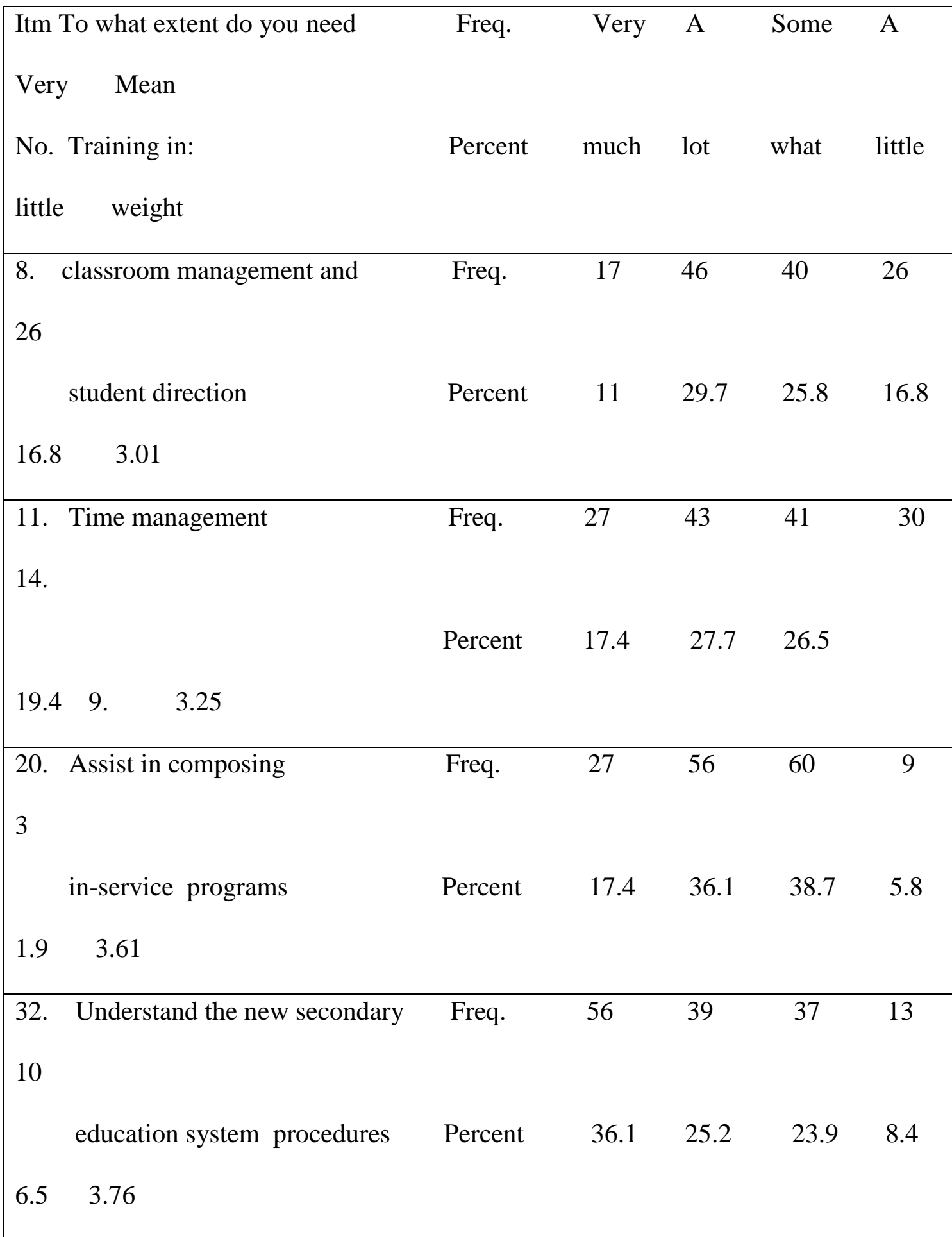


The mean score for The responses varied from 3.01 to 3.76 .

Table VII- To what extent do high school teachers need human relational?

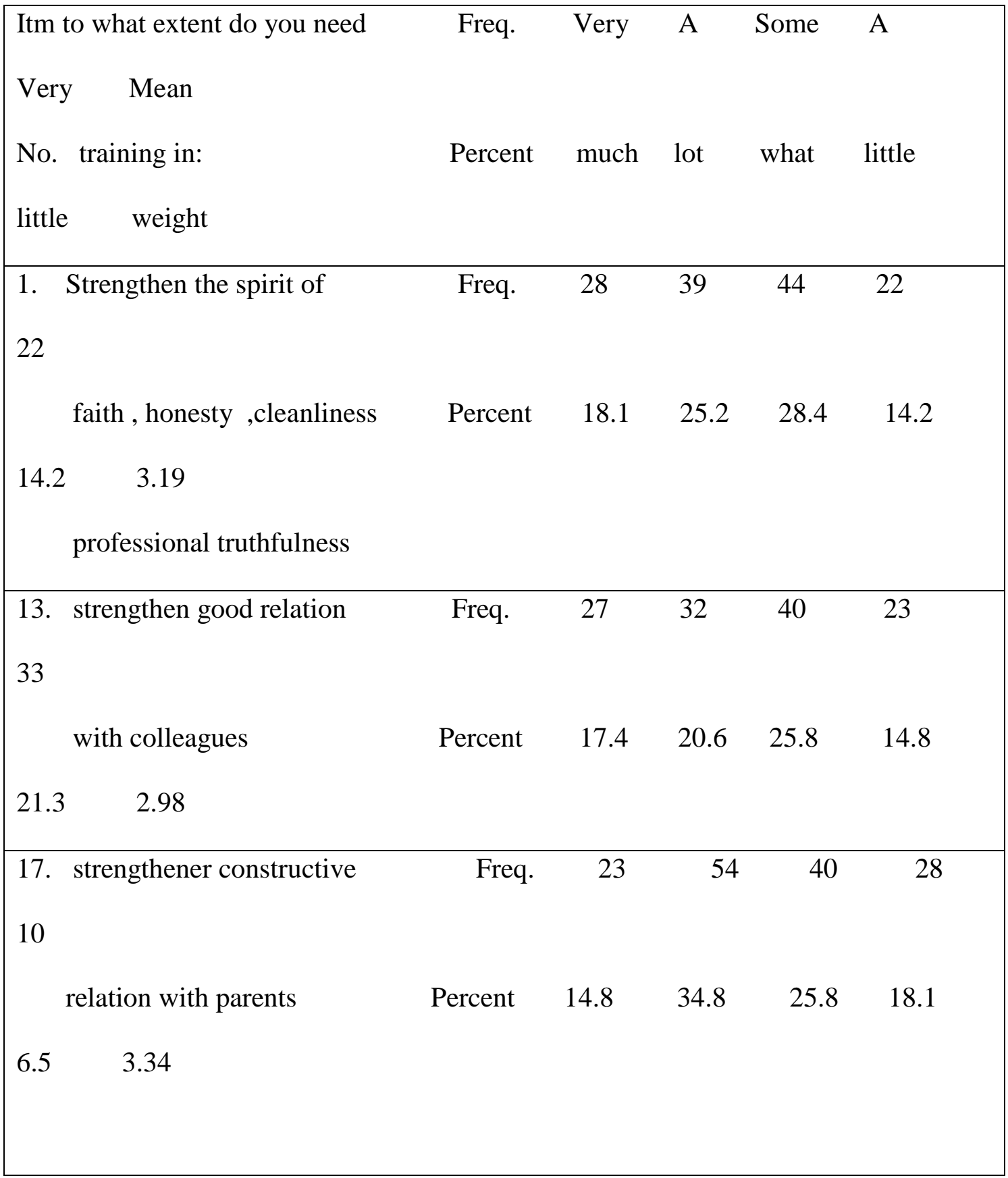

The mean score for the responses Ranged from 2.98 to 3.34 .

Table VIII-comparison of the mean rank Educational degrees

\begin{tabular}{|l|l|l|l|l|l|}
\hline Varied academic degrees & High & Bachelor,s & Master's & & \\
& school & degree & degree & & \\
\hline
\end{tabular}




\begin{tabular}{|c|c|c|c|c|c|}
\hline \multirow[b]{2}{*}{ Varied needs } & Diploma & & & \multirow[t]{2}{*}{$\mathrm{P}$} & \multirow[t]{2}{*}{$\mathrm{H}$} \\
\hline & $\begin{array}{l}\text { Mean } \\
\text { Rank }\end{array}$ & $\begin{array}{l}\text { Mean } \\
\text { Rank }\end{array}$ & $\begin{array}{l}\text { Mean } \\
\text { Rank }\end{array}$ & & \\
\hline 1.Job skills & 88.03 & 77.36 & 58.92 & $\begin{array}{l}0.156 \\
6\end{array}$ & $\begin{array}{l}3.70 \\
83\end{array}$ \\
\hline $\begin{array}{l}\text { 2.Counselling and Advisory } \\
\text { services }\end{array}$ & 88.27 & 79.36 & 49.50 & $\begin{array}{l}0.062 \\
4\end{array}$ & 5.5496 \\
\hline $\begin{array}{l}\text { 3.Technology and audiovisual } \\
\text { aids }\end{array}$ & 87.80 & 78.65 & 69.83 & $\begin{array}{l}0.802 \\
5\end{array}$ & $\begin{array}{l}0.44 \\
00\end{array}$ \\
\hline 4.Psychology & 84.10 & 78.17 & 61.17 & $\begin{array}{l}0.324 \\
1\end{array}$ & $\begin{array}{l}2.25 \\
32\end{array}$ \\
\hline $\begin{array}{l}\text { 5.Testing and evaluational } \\
\text { devices }\end{array}$ & 88.70 & 78.12 & 50.13 & $\begin{array}{l}0.040 \\
5\end{array}$ & $\begin{array}{l}6.41 \\
19\end{array}$ \\
\hline 6.Management planning & 72.73 & 81.04 & 62.58 & $\begin{array}{l}0.306 \\
4\end{array}$ & $\begin{array}{l}2.36 \\
57\end{array}$ \\
\hline 7.Human Relations & 84.83 & 79.80 & 43.96 & $\begin{array}{l}0.019 \\
7\end{array}$ & $\begin{array}{l}7.58 \\
26\end{array}$ \\
\hline
\end{tabular}

Hcr $(\mathrm{dfz}, \mathrm{a} 0.05)=5.99$ 
As the computed $\mathrm{H}$ for evaluation and human relations is greater than the critical value at 5\% Error level, the rankings for high school teachers with varied academic degrees are not the same.

\section{Discussion and conclusion}

The results from karbassyoun's study (1994) refers to "Understanding the Methods and Techniques of Teaching "as an important training need for most teachers, a fast that Supports the findings of this study and that high school teachers have referred to "Understanding The Various Teaching Strategies " as the greatest educational need.

It can be concluded from the findings of this study that the majority of high school teachers $(81 \%)$ have expressed their greatest need for education aids, which compares to the result from the studies conducted by Bowen (1994), Karbassyoun (1994), and Ali Beigi (1996).All such studies have emphasized the necessity for learning educational technology: audio-visual aids, communication media, video presentations, computer and educational animation. Thus, the InService Education Department will have to grant a first priority to this high school teachers' Need, taking the necessary measures to meet this need and implementing the theoretical and practical training programs on technology for all high school teachers' . as regards technology and educational Aids, high school teachers have expressed their smallest need for using newspapers in the process of teaching. Hence, it is highly recommended that newspapers and authoritative magazine be used by high school teachers in the process of teaching and in the classroom and be made available to students so that a constructive step be taken toward propagation of reading as an institution . 
Acounga (1993 ) presents “Testing” as a qualification needed by educators . The results from this study also support this point. The greatest need for testing and human relations was expressed by high school teachers holding high school diplomas and the smallest need by high school teachers holding Master's degrees . There fore, it can be concluded that for testing and human relations, education has managed to play a good part but little for other areas. Hence, the Ministry of culture and Higher Education is advised to meet the following in order to overcome this problem :

1.Analyse and revise the content of university textbooks

2.Reflect, examine and revise the testing system used for higher education purposes

3.Precisely survey and identify the university professors' and faculties' educational need in other to take the necessary steps to meet it.

The result from this study indicate that the "experience" factor (years of service ) has failed to Play a good part in meeting the educational needs of high school teachers, which do not Support the result from the studies by Fagihi Rezaei (1995 ), Karbassyoun (1994 ), Ali Beigi (1996 ) and Moussaie (1997 ). Surprisingly enough, every year every effort is made to select and present an exemplar teacher from the experienced high school teachers. Why?

Why are only experienced teachers honoured with incentive promotions? This being the case, It is highly recommended that evaluations be rather based on such objective criteria as expertise, Knowledge, quality performance and Job commitment . 
The result from this study indicate that female high school teachers have expressed greater need Than men in counselling and advisory services, testing, management and planning. Thus, the In- Service Education is advised to incorporate the requisite training programs for female Teachers upon their return from relatively long vacation, e. g. Child-delivery, one-year vacations, Etc. Such that their backwardness and previous separation from the educational environment Might be compensated .

Further, as $71 \%$ of the social sciences high school teachers have expressed their need for Counselling and advisory services at a medium level, it is recommended that training Programs related to counselling and advising services be planned and executed for high School teachers by In-Service Education .

\section{References}

1. Abedil. "A study of suitable ways of literacy Training Program in Adaptation to literacy trainees needs and conditions.” M.A. Dissertation, University of isfahan ,faculty of education ,Isfahan :1991

2. Alibeigi,A “ A survey of promoters ' training Needs and protections of Agricultural Services of Isfahan Province centres.” M . A Dissertation in promotion and training, University of tarbiat Moddares Agriculture faculty , Tehran 1996.

3. Boyle, P.G "Planning in development process “. Translated by Gholamreza, 1981

4. Faghihi Rezai, M. “Training needs Assessment of Jahad -e-Sazandegi promotion directors “ M. A Dissertation in Agricultural promotion and training .University of Tarbiat Moddaress, Agriculture Faculty . Tehran :1996. 
5. Fathi .Vajorgah ,K “An Introduction in employees' in-Service training programs “ Tehran :Salamat kavoush, 1996.

6. Holinshid, B ."Technical and professional Training Process and development " Translated by : A. Maleki Shemshadi , Tehran : National Publication of UNESCO , 1996

7..Karbasian, M.” Training needs Assessment and Teaching abstractions of Isfahan Province Trainers in villagers Training Program “, M. A. Dissertation , Tehran : tarbiat Moddares University ,1996.

8. Nasiri M. “ Training needs assessment of Elementary schools teachers in Hormozgan Province “, The centre of information and scientific procurements of Iran, Iran dissertations Abstracts , No . 19,1994 